\author{
Л.Г. Агамов ${ }^{1}$, С.В. Кубарь ${ }^{1}$, В.А. Храмченко ${ }^{1}$ \\ ${ }^{1}$ Державний науково-дослідний інститут авіачії, Київ
}

\title{
ОБГРУНТУВАННЯ КРИТЕРІЇВ ПРИЙНЯТТЯ ТЕХНІЧНИХ РІШЕНЬ ЩОДО ДОПУСКУ ДО ВИКОНАННЯ ЗАВДАНЬ ЛІТАКІВ 3 ВІДМОВАМИ ОКРЕМИХ ВИРОБІВ БОРТОВОГО ОБЛАДНАННЯ
}

\begin{abstract}
Запропоновано критерії прийняття рішень щодо допуску військових літальних апаратів до виконання бойових завдань з відмовами окремих виробів бортового обладнання на основі оцінки ефективності виконання цих завдань. Для спрощення процедури розрахунків пропонується замість матриці ефективності складати матрицю коефіцієнтів ефективності. Припускається, що зниження ефективності за час польоту буде пропориійне зниженню ймовірності безвідмовної роботи тієї функиіональної групи виробів бортового обладнання, до складу якої входить виріб, що відмовив.
\end{abstract}

Ключові слова: бортове обладнання, військовий літальний апарат, технічний стан, прийняття технічних рімень, критерії ефективності.

\section{Вступ}

В особливий період нормативними документами передбачено випускати в політ військовий літальний апарат (ЛА) 3 відмовами окремих систем, якщо вони не вплинуть на безпеку польоту і працездатність інших систем, або не будуть використовуватися в даному польоті. Але правила прийняття цього рішення документально не формалізовані. Бортове обладнання (БО) ЛА характеризується наявністю у його складі функціонально пов'язаних виробів, систем i комплексів, що ускладнює процедуру прийняття рішення щодо допуску ЛА до виконання бойового завдання за можливими варіантами бойового спорядження (ВБС) з відмовами окремих виробів БО. Тому виникає актуальне науково-технічне завдання щодо формалізації процедури прийняття такого рішення.

Аналіз попередніх досліджень показує, що класичні методи прийняття рішень знайшли широке застосування в різних прикладних областях [1...5]. При цьому надано основні аспекти системного підходу щодо дослідження ефективності прийняття рішення на етапі проєктування (модернізації) складних систем.

Прийняття рішення являє собою вибір одного 3 деякої множини варіантів. Найбільш часто на практиці зустрічається випадок, коли $є$ кінцева множина варіантів i для кожного варіанта однозначно встановлено деякий результат.

Ці результати повинні допускати кількісну оцінку, наприклад, виграшу, корисності, надійності тощо, на підставі чого визначають найкращий варіант.
Пошук оптимального рішення виконують за допомогою критерію, вибір та обгрунтування якого $\epsilon$ одним 3 найважливіших етапів досягнення поставленої мети. Критерій прийняття рішення функціонал, що виражає переваги того чи іншого варіанта та визначає правило, відповідно до якого обирається прийнятний або оптимальний варіант рішення.

Проведений аналіз методів прийняття рішень дозволяє стверджувати, що вони не враховують особливості прийняття рішень щодо допуску військових ЛА з відмовами окремих виробів БО до виконання завдань в особливий період. Тому мета статті полягає у визначенні критеріїв прийняття технічних рішень щодо допуску до виконання завдань в особливий період військових ЛА 3 відмовами окремих виробів БО.

\section{Виклад основного матеріалу}

В умовах ведення бойових дій постійно виникає необхідність після виконання конкретного бойового завдання кількісно оцінювати результати бойового застосування ЛА. Отже, має бути показник, за яким можна оцінювати результативність (ефективність) бойового застосування ЛА. Як критерій бойової ефективності використовують спеціальним способом обраний показник.

Як відомо [6], зміст i вигляд показника залежить від бойового завдання, особливостей бойового застосування авіаційного комплексу, БО ЛА зокрема, вимог, що їх висувають до властивостей і процесу функціонування ЛА. 
Розрізняють загальні та часткові критерії бойової ефективності авіаційних комплексів. Загальні критерії бойової ефективності являють собою показники, за числовими значеннями яких оцінюють результати функціонування авіаційних комплексів у цілому. Часткові критерії ефективності - це показники ефективності виконання окремих етапів бойового процесу тими елементами авіаційного комплексу, що функціонують на відповідних етапах.

Формалізацію процесу виконання етапів бойового завдання авіаційними комплексами будемо здійснювати за допомогою відомих апробованих методів та математичних залежностей теорії бойової ефективності [6].

Оцінювати ефективність виконання етапу польоту (польотного завдання в цілому) можна на основі методів безпосереднього та непрямого порівняння.

Методи безпосереднього порівняння передбачають детальний розрахунок ефективності виконання кожного етапу польоту з урахуванням стану БО. Ці методи забезпечують високу точність визначення ефективності у разі, якщо дослідник знає функцію залежності іiі від технічного стану авіаційного комплексу, того чи іншого виробу БО зокрема.

Методи непрямого порівняння базуються на відносному зіставленні варіантів без розрахунку абсолютних значень показників ефективності. Простота розрахунків i наочність порівняння дозволяють розширити множину розглядуваних станів БО. Порівнювання непрямими методами можна виконувати як за частковими показниками (тактичними, технічними параметрами, питомими характеристиками), так і за узагальненими параметрами.

Як один із критеріїв бойової ефективності можна прийняти ймовірність виконання бойового завдання $E_{53}$. Для літаків-винищувачів це може бути ймовірність перехоплення $E_{\text {nер }}$. Для літаківбомбардувальників - ймовірність ураження наземної цілі $E_{\text {ураж }}$. Для розвідувальних літаків слід використовувати ймовірність виявлення наземного об'єкта $E_{\text {вияв }}$.

Процес функціонування можна розбити на окремі проміжні етапи (події), а кінцевий результат подати як добуток цих подій. Тоді ймовірність його досягнення можна представити як добуток імовірності здійснення всіх проміжних етапів. При цьому припускаємо, що результат виконання завдання кожного етапу - незалежні випадкові події $[7$, c. $33 \ldots 34 ; 8$, c. 48$]$.

Для винищувальних авіаційних комплексів при виконанні перехоплення повітряної цілі ймовірність виконання перехоплення

$$
E_{\text {пер }}=P_{0} \cdot P_{H} \cdot P_{\text {уражс }},
$$

де $P_{0}-$ імовірність своєчасного вильоту на перехоплення повітряної цілі, що характеризує ефективність засобів системи бойового управління, технічних засобів інженерно-авіаційного й аеродромно-технічного забезпечення; $P_{H}-$ імовірність наведення винищувача на повітряну ціль, що характеризує ефективність наземних систем управління і БО; $P_{\text {ураж }}-$ імовірність ураження повітряної цілі бортовими засобами озброєння, що характеризує ефективність бортового комплексу озброєння винищувача.

Для ударного авіаційного комплексу під час дії по одиночному об'єкту ймовірність виконання бойового завдання (ураження наземної цілі)

$$
E_{\text {уражс }}=P_{0} \cdot \bar{P}_{\text {ППО }} \cdot P_{\text {вих }} \cdot P_{\text {уражс }},
$$

де $P_{0}-$ імовірність своєчасного вильоту чи ймовірність своєчасної появи ударного ЛА над ціллю, що характеризує ефективність наземної системи бойового управління, а також технічних засобів інженерно-авіаційного i аеродромнотехнічного забезпечення; $\bar{P}_{\text {ППО }}-$ імовірність подолання протиповітряної оборони (ППО) противника чи ймовірність того, що ЛА залишиться неураженим під час діяння по ньому засобів ППО противника, що характеризує ефективність бортових засобів захисту, засобів радіоелектронного подавлення, а також бойову живучість конструкції ЛА; $P_{\text {виx }}$ - імовірність виходу ударного ЛА на лінію бойового шляху, що характеризує ефективність наземної системи наведення та БО ЛА;

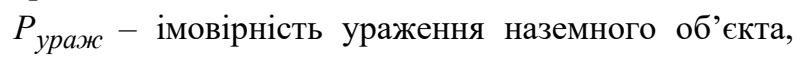
що характеризує ефективність бортового озброєння ударного ЛА.

Для оцінювання ефективності розвідувального авіаційного комплексу, основним елементом якого $є$ розвідувальний літак, як безпосередній критерій ефективності, доцільно використовувати ймовірність виявлення наземного об’єкта та доставки інформації про нього розвідувальним ЛА, a саме:

$$
E_{\text {вияв }, \partial}=P_{0} \cdot \bar{P}_{\text {ППО }} \cdot P_{\text {вих }} \cdot P_{\text {вияв }, \partial},
$$

де $P_{0}$ - імовірність своєчасної появи розвідувального ЛА над об'єктом розвідки; $\bar{P}_{\text {ППО }}$ - імовірність того, що розвідувальний ЛА залишиться неураженим під час проходження системи ППО; $P_{\text {вих }}$ - імовірність виходу в район розвідки; $P_{\text {вияв }, \partial}$ - імовірність виявлення наземного об'єкта та доставки інформації про нього на командний пункт, що характеризуе ефективність бортового розвідувального комплексу. 
Отже, як критерій ефективності виконання бойового завдання літаком-винищувачем пропонується використовувати критерій (1), літаком-бомбардувальником - критерій (2), а розвідувальним літаком - критерій (3).

Введемо поняття "умовно працездатний стан літака” - стан літака, за яким з усіх польотних завдань або ВБС, передбачених керівництвом 3 льотної експлуатації, можна без впливу на безпеку польотів виконати тільки одне чи декілька завдань 3 потрібною ефективністю [9, с. 80; 10, с. 232...236].

Критерій прийняття рішення має полягати у виборі найбільш переважного варіанта досягнення заданої мети 3 деякої множини припустимих альтернатив. $€$ кінцева множина альтернатів $E_{1}, E_{2}$, $E_{3}, \ldots, E_{\kappa}$. Кожному варіанту $E_{i}$ відповідає деякий результат $e_{i}$. Тобто, для умовно працездатного стану $S_{i}$ вибираємо варіант (варіанти) бойового спорядження $B_{j}$, для якого (яких)

$$
e_{B} \geq e_{\text {npun }}: \max _{i j} e_{i j}\left\{\forall S_{i} \exists B_{j}\right\} \text {, }
$$

де $e_{6}-$ відповідний визначеним умовам та завданням рівень ефективності, який розраховують згідно 3 (1), (2), (3); $e_{\text {nрип }}$ - припустимий рівень ефективності, який встановлюють нормативно; $i=\overline{1, n}, \quad n-$ кількість умовно працездатних станів ЛА через відмови виробів БО; $j=\overline{1, m}, m-$ кількість ВБС ЛА.

Якщо для $i$-го стану ЛА вимогу (4) не виконано, то цей стан не включають до переліку умовно працездатних станів ЛА.

Система прийняття технічних рішень щодо допуску ЛА з відмовами окремих виробів БО до виконання завдань в особливий період - це система, в якій рішення приймають шляхом вибору однієї із декількох альтернатив. Тому інформаційна підтримка повинна базуватись на алгоритмічному забезпеченні прийняття рішення, оформленого як нормативний документ, в основу якого покладено досвід, знання фахівців та функціональні зв'язки технічних систем.

Розробити зазначений документ можна за таких умов $[9$, с. 80$]$ :

визначено вектор-рядок $\left\{S_{i}\right\}, i=\overline{1, n} \quad$ станів літака;

визначено (задано) вектор-стовпець $\left\{B_{j}\right\}, j=\overline{1, m}$ ВБС;

складено матрицю ефективності $\left\|E_{j i}\right\|$;

$\epsilon$ відомі досягнуті показники безвідмовності виробів БО кожного типу; задано вимоги (обмеження) щодо припустимого зменшення ефективності виконання польотного завдання.

Через велику складність процесу визначення всіх елементів матриці $\left\|E_{j i}\right\|$ запропоновано замість матриці ефективності складати матрицю $\left\|K_{j i}\right\|$ коефіцієнтів ефективності [10, с. 232..236]. Під коефіцієнтом ефективності $K_{j i}$ будемо розуміти порівняльну оцінку ефективності умовно працездатного й працездатного станів літака, а саме: $K_{j i}=E_{j i} / E_{j}$, де $E_{j}-$ ефективність виконання $j$-го польотного завдання (застосування $j$-го ВБС) за умови випуску в політ працездатного літака, тобто без відмов виробів БО.

Можна припустити, що зниження $E_{j i}$ за час польоту $t_{n}$ буде пропорційне зниженню ймовірності безвідмовної роботи тієї функціональної групи виробів БО, до складу якої входить виріб, що відмовив, тобто $K_{j i}=P_{j i}\left(t_{n}\right) / P_{j}\left(t_{n}\right)$.

Імовірність $P_{i}\left(t_{n}\right)$ безвідмовної роботи виробу $\boldsymbol{i}$-го типу за час польоту $t_{n}$ розраховують за формулою основного закону надійності $[11$, с. 27 ; 12 , c. $18 \ldots 20]$ :

$$
P_{i}\left(t_{n}\right)=e^{-t_{n} / T_{\Pi i}}
$$

де $T_{\Pi i}-$ наліт на відмову в польоті виробу $\boldsymbol{i}$-го типу.

Показник $T_{\text {Пi }}$ розраховують за формулою:

$$
T_{\Pi i}=\frac{T_{\text {лim }}}{M_{\text {BПi }}},
$$

де $T_{\text {літ }}$ - наліт літаків за деякий період навчальнобойової підготовки; $M_{B П i}-$ кількість відмов у польоті виробів $i$-го типу за зазначений період.

Отже, якщо складено матрицю $\left\|K_{j i}\right\|$, то можна для кожного умовно працездатного стану визначити варіант (варіанти) бойового спорядження літака та покласти отримані результати в основу проєкту нормативного документа.

Під час розробки методичного апарату інформаційної підтримки прийняття рішень про допуск ЛА з відмовами окремих виробів БО до виконання завдань в особливий період необхідно, 3 урахуванням підходів [2..6], передбачити: визначення всіх можливих реконфігурацій БО для виконання польотного завдання з визначеним ВБС; обчислення для кожної реконфігурації БО бойової ефективності ЛА; розроблення правила прийняття рішення; нормативне закріплення правила прийняття рішення. 


\section{Висновки}

Запропоновані критерії можуть бути застосовані у методичному апараті прийняття рішення щодо допуску ЛА до виконання завдань 3 відмовами окремих виробів БО. Тому напрямом подальших досліджень має бути визначення всіх елементів матриці ефективності для різних типів авіаційних комплексів та формування на особливий період регламентів технічного обслуговування визначених типів бойових літаків Повітряних Сил Збройних Сил України щодо їх допуску до виконання завдань з відмовами окремих виробів БО.

\section{Список літератури}

1. Сложные технические и эргатические системы: методы исследования / А.Н. Воронин, Ю.К. Зиатдинов, А.В. Харченко, В.В. Осташевский. - Харьков: Факт, 1997. - 240 с.

2. Мушик Э., Мюллер П. Методы принятия технических решений: Пер. с нем. - М.: Мир, 1990. - 208 с.

3. Кини Р.Л., Райфа Х. Принятие решений при многих критериях: предпочтения и замещения. - М.: Радио и связь, 1981. $560 \mathrm{c}$.

4. Саати Т. Принятие решений: Метод анализа иерархий. - М.: Радио и связь, 1989. - 316 с.

5. Нейман Дж., Моргенштерн О. Теория игр и экономичное поведение. - М.: Наука, 1970. - 704c.

6. Мильграм Ю.Г., Попов И.С. Боевая эффективность авиационной техники и исследование операций. - М.: ВВИА им. проф. Н.Е. Жуковского, 1970. - 500 с.

7. Прохоров Ю.В., Розанов Ю.А. Теория вероятностей. Основные понятия. Предельные теоремы. Случайные процессы. - М.:, Наука, 1970. - 704 с.

8. Мавренков О.С., Улізько В.І., Раєв К.М. Оцінювання ефективності бойового застосування протичовневих вертольотів методами математичного моделювання. // Зб. наук. праць. - К.: ДНДІА, 2018. - Вип. 14(21). - С. 44-49.

9. Храмченко В.А. Щодо формалізації процедури допуску до польоту військової авіаційної техніки 3 відмовами виробів бортового обладнання. / Тези доповідей та виступів учасників НПК 25 червня 2015 р “Актуальні проблеми розвитку авіаційної техніки та досвід їі експлуатації в особливий період.” - К.: ДНДІА, 2015. - С. 80.

10. Храмченко В.А., Дудкін І.П., Агамов Л.Г., Вознюк М.М. Методичний апарат інформаційної підтримки прийняття рішення про допуск військової авіаційної техніки з відмовами окремих виробів бортового обладнання до виконання завдань в особливий період. // Зб. наук. праць. - К.: ДНДІА, 2016. - Вип. 12(19). - С. 232-236. $406 \mathrm{c}$.

11. Дедков В.К., Северцев Н.А. Основные вопросы эксплуатации сложных систем. - М.: Высшая школа. 1976. -

12. Барлоу Р., Прошан Ф. Математическая теория надежности. Пер. с англ., под ред. Б.В.Гнеденко. - М.: Советское радио, 1969. - 488 с.

\section{Відомості про авторів:}

\section{Агамов Лев Гаврилович}

кандидат технічних наук

доцент

провідний науковий співробітник

Державного науково-дослідного інституту авіації,

Київ, Україна

https://orcid.org/0000-0001-6010-0933

\section{Кубарь Сергій Володимирович}

кандидат технічних наук

старший науковий співробітник

начальник науково-дослідного управління

Державного науково-дослідного інституту авіації,

Київ, Україна

https://orcid.org/0000-0001-8165-7140

\section{Information about the authors:}

\section{Lev Ahamov}

Candidate of Technical Sciences

Associate Professor

Leading researcher

of State Research Institute of Aviation,

Kyiv, Ukraine

https://orcid.org/0000-0001-6010-0933

\section{Serhii Kubar}

Candidate of Technical Sciences

Senior Researcher

Head of Research Management

of State Research Institute of Aviation,

Kyiv, Ukraine

https://orcid.org/0000-0001-8165-7140 
Храмченко Вячеслав Анатолійович

кандидат технічних наук

доцент

провідний науковий співробітник

Державного науково-дослідного інституту авіації,

Київ, Україна

https://orcid.org/0000-0001-8462-4184

\author{
Viacheslav Khramchenko \\ Candidate of Technical Sciences \\ Associate Professor \\ Leading Researcher \\ of State Research Institute of Aviation, \\ Kyiv, Ukraine \\ https://orcid.org/0000-0001-8462-4184
}

\title{
THE SUBSTANTIATION OF CRITERIONS OF ACCEPTANCE OF ENGINEERING SOLUTIONS ABOUT THE ADMISSION TO FULFILMENT OF THE TASKS OF AIRPLANES WITH REFUSALS OF SEPARATE ITEMS OF THE ONBOARD EQUIPMENT
}

\author{
L. Ahamov, S. Kubar, V. Khramchenko
}

The article represents outcomes of the analysis of a problem of maintenance of information support of decisionmaking by the managers of air parts about the admission to battle flight of flight vehicles with separate refusals of items of the onboard equipment. Search of an optimum solution execute with the help of criterion, the choice and which substantiation is one from major stages of reaching of object in views. For a quantitative estimation of outcomes of battle application of flight vehicles by the authors it is offered to use a criterion of battle efficiency. As one from criterions of battle efficiency the probability of fulfilment of the battle task is accepted. The process of operation is devided into separate gaps event, and the eventual result moves as a multiplication of these events. Then the probability of its reaching can be presented as a multiplication of probabilities of a realization of all intermediate stages. The criterion of decisionmaking consists in choice most of primary variant of reaching of the specific purpose from some set of admissible alternatives. To each variant there corresponds some outcome. For conditional up states (with allowance for of refusals of separate items) the variant of battle equipment is selected, for which the level of efficiency will be equal or large allowable, which install normatively. The information support bases on algorithmic maintenance of decisionmaking which was made out as the normative document. For simplification of a procedure of accounts it is offered instead of a matrix of efficiency to make a matrix of effectiveness ratio, where factor of efficiency is understood as a comparative evaluation of efficiency conditionally of serviceable and serviceable condition of a airplane. It is supposed, that the decrease of efficiency during flight will be proportional to decrease of probability of non-failure of that functional group of items of the onboard equipment, up to which structure the item enters, which has given up. The offered criterions of decisionmaking can be applied in a methodical means of decisionmaking, which will enable The substantiation to complete on especial period the normative documents for battle flight vehicles about their admission to fulfilment of the tasks with refusals of separate items of the onboard equipment.

Keywords: the onboard equipment, military air engineering, availability index of product, acceptance of engineering solutions, criterions of efficiency. 